\title{
AGONISTIC INTERACTION BETWEEN RHESUS MONKEY AND HUMAN AT SWAYAMBHU AND PASHUPATI AREA, NEPAL
}

\author{
Sunil Khatiwada and Mukesh K. Chalise \\ Central Department of Zoology, Tribhuvan University, Kritipur, Kathmandu, Nepal
}

Corresponding author Email: mukesh57@ hotmail.com

\begin{abstract}
The study was designed using Scan Sampling and Ad libitum recording to investigate the interaction between Rhesus monkey and Humans in Pashupatinath Temple Area and Swayambhunath Stupa Area for a total of 250 hours (8 hours per day; from 9:00 a.m.-5:00 p.m.). Interactions at Swayambhu were occurring high in midday (1p.m. to 2 p.m.) and at Pashupati interactions were occurring high in morning (10 a.m. to 11 a.m.) and evening (4 p.m. to 5 p.m.). Monkey interacted more for the context of food while humans interacted for recreation purpose. Biting was observed only in Swayambhu area. Agonistic behaviour by human was $44 \%$ at Pashupati and $34.7 \%$ at Swayambhu and Agonistic monkey behaviour was $23.1 \%$ at Swayambhu while $22.4 \%$ at Pashupati. Living in commensalism with human agonistic behaviour of monkey was high in response to human behaviour rather than through its initiation and also monkeys' have devised passive behavior strategy during presence of food. Threat shown by monkey at both places tends to increase in absence of food. Female monkey individuals residing in Swayambhu initiate more encounters (58\%) than of Pashupati (28\%) area while the overall encounter was accounted for male individual. Female monkey individuals were likely to start an encounter at Swayambhu preferring agonistic behaviour during encounter than male individuals while at Pashupati male monkey individual were likely to prefer agonistic behaviour.
\end{abstract}

KEYWORDS: Urban Rhesus-Human Conflict, Agonistic Behaviour, Nepal.

Nepalese Journal of Zoology | Online Volume 3 Issue 1 | November 2015 | Page 82 


\section{INTRODUCTION}

Different types of urban habitat support different kinds of wildlife. Urban wildlife, also referred as a synanthrope, has well adapted and suited themselves with human made environment and lives side by side in association with human element which also often lead to extreme case of conflict. With increased population and fragmentation of habitat, human-wildlife conflict is certainly bound to occur. The phrase 'human-wildlife conflict management' is being applied to situations that involve any negative interactions between humans and wildlife (Messmer 2000). Urban wildlife such as Rhesus Macaque (Macaca mulatta Zimmermann, 1780), is exposed to stress condition of human presence creates unlike wild population. Fragmentation in habitat through deforestation has pushed primates into areas of human settlement and agricultural lands leading to conflict (Marsh 2003). These wildlife populations adapt and modify their behaviour according to urban stresses (Ditchkoff et al. 2006).

In Nepal, six species of monkey are recorded with major three species the Rhesus, Assamese spp. and Langur spp. (Chalise 2008). Rhesus monkey has been observed living in close association with humans (Chalise 2008a). The rhesus in Kathmandu is localized basically in religious areas, such as Pashupati, Swayambhunath, Nilbarahi, Thapathali, Sankhu-Bajrajogini etc. Population of approximately 400 monkeys in seven-eight social groups live at Swayambhu, near around in Pashupatinath population of 300 monkeys live, fragmented population of about 40 Rhesus monkeys reside in the Thapathali area and about 100 monkeys in Sankhu-Bajrajogini (Chalise 1998, 2013). They come in close contact with humans for sharing resources such as space and for food as well. In the temple areas such as Pashupati and Swayambhu monkeys are frequently snatching away possessions of humans. The monkeys are not harmed by humans in Nepal due to their religious belief and are hence under some sort of protection. Rhesus Macaque, lives in large group showing continuous interaction among them (Chalise 2008). There exist a type of commensalism interaction between human and monkey.

Agonistic behaviour is defined as "Any activity related to fighting whether aggression or conciliation and retreat" (Scott and Fredericson 1951). Study of agonistic behaviour focuses on behaviour such as threat, aggression and submission, which are found in successional pattern from the beginning to the end of the interactions (McGlone 1986). Such behaviour is studied collectively or any one form of the behviour is studied alone. In urban areas due to artificial feeding the aggressive competitive behaviour within monkey is also seen to increase (Southwick et al. 1976). Behaviour study of animal and specially primates was systematically initiated since the 70s (Altmann 1974). Aggression were generally higher per male monkey than per female by analyzing aggressive acts like threats, chases, attacks, fights directed at other species (principally humans) of Kathmandu (Teas et al. 1982).

Presence of wildlife in urban area had always been of high concern. Moreover when there is presence of wildlife such as Monkey in religious areas their interaction and conflict with humans occurs in regular basis. Monkey has been long observed to create a lot nuisance disturbing human and damaging their property. Study on urban wildlife is minimal and there has been a long gap on works related to conflict between monkey and human.

\section{MATERIALS AND METHODS}

From preliminary observation a troop of monkey were selected and the route the troops took to move was marked in study area at Swayambhu (27.7116-27.7177 latitude north and 85.2841-85.2952 
longitude East) and Pashupati (27.7041-27.7152 latitude North and 85.3461-85.375 longitude East). The study area, comprising of isolated population of Rhesus Macaque adapted to urban environment, was widely intermixed with human settlement with traces of forest area. Study was carried out over a time period of 250 hours ( 8 hours a day) making observation points in each area; one where visitors spent time performing various recreational activities and the other place was in the core temple area. Encounters were recorded when both interactor; humans and monkeys, were within the two metre distance. Interaction between rhesus and human related to agonistic encounter was recorded using Scan sampling, along with some ad libitum recording, method useful for direct observation to record rare but fairly obvious behaviours (Altman 1974). Observational study of Hinde and Rowell (1962), Sade (1973) on behavioural description of threat, attack, and fear was combined with personal field recording for data acquisition. Field data were recorded moving constantly and periodically around the designated study site from 9:00 a.m. in the morning to 5:00 p.m. for total of 250 hours.

Cross tabulation method was used in IBM SPSS statistics 21 to measure association between categorical variables such as "Encounter", "Food" and "Sex". Each variable was further categorised into two levels. Encounter was categorized into aggression and passive. Food was categorized into present and absent. Sex was categorized into male and female. Interacting individuals were classified into two types, human and monkey. Sex of each type was further separated into male and female. Each association was observed under "P" value. "P" value less than 0.05 lead to rejection of null hypothesis under each model of association.

\section{RESULTS}

Observation of Human and Rhesus monkey interaction at two places; Swayambhunath Stupa Area and Pashupatinath Temple Area showed that there were more interactions in Swayambhu area (769) than Pashupati area (510) (i.e. nearly about 3:2 hourly interactions) where Humans initiated most encounter at both sites and the initiation among monkey was seen to be high in Swayambhu while comparing to Pashupati. In both study place monkeys were more interactive for food $(78 \%$ at Swayambhu and $73 \%$ at Pashupati) and humans for recreation purpose (78\% at Swayambhu and $75 \%$ at Pashupati). Share in encounter by age group is listed in Table 1.

Table 1. Share of encounters according to age group by human and monkey, 2014/015.

\begin{tabular}{|l|l|l|l|l|l|l|}
\hline & \multicolumn{4}{|l|}{ Monkey } & \multicolumn{2}{l|}{ Human } \\
\hline & Adult & Young & Infant & Adult & Young & Infant \\
\hline Swayambhu & 250 & 71 & 3 & 337 & 65 & 43 \\
\hline Pashupati & 108 & 51 & 2 & 238 & 69 & 42 \\
\hline
\end{tabular}

Hourly interaction in Fig.1 reveals that at Swayambhu interaction gradually increased over time with highest interaction during 1:002:00 p.m. (136 encounters) and then decreased until 5:00 p.m. in contrast at Pashupati interaction increased becoming highest at 10:00-11:00 a.m. (83 encounters) and then decreased throughout the day finally increasing from 4:005:00 p.m. again (86 encounters).

Nepalese Journal of Zoology| Online Volume 3 Issue 1 | November 2015 | Page 84 


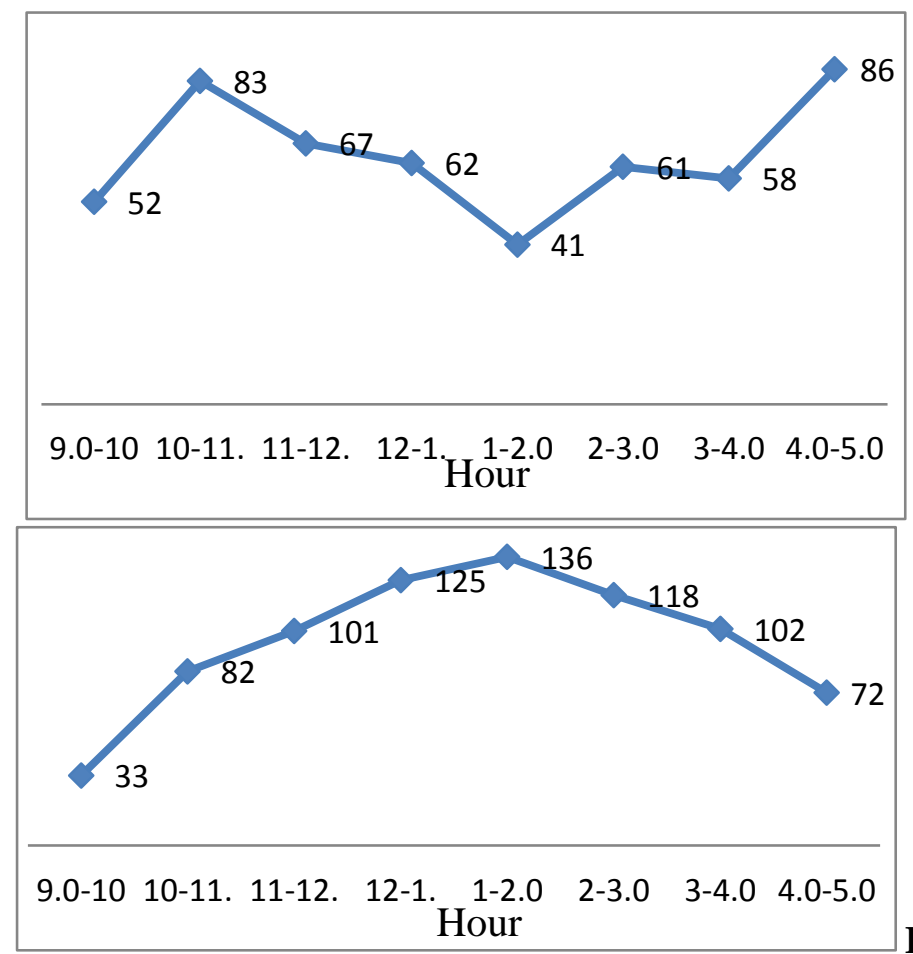

(Top) and Swayambhu (Bottom)

Fig 1. Hourly encounter at Pashupati

\section{Behavioural Aspect}

\section{In Swayambhu}

$23.1 \%$ of the total encounter accounted for agonistic monkey behaviour; $11.4 \%$ threat, $7.1 \%$ attack/charge, $1.5 \%$ biting, $3.1 \%$ chase. $52.8 \%$ of the behaviour was passive behaviour and $24.1 \%$ accounted for joyful physical contact initiated by monkey at Swayambhu. Human responses were shown through behaviour such as; chase $(30 \%)$, watch $(23 \%)$, flee $(20 \%)$, retreat (13\%), feeding $(10 \%)$, and leave (4\%).

In Human behaviour, $31.2 \%$ was allocated for feeding, $27.1 \%$ recreational activity of taking photo, $34.7 \%$ for agonistic (28.9\% for threat and $5.8 \%$ chase), $2.5 \%$ touch, $2.2 \%$ moving close, $2.2 \%$ just watch. Passive responsive behaviour of monkey such as eating, flee, no interest, watch, leave, move close, and physical contact accounted to be $27.8 \%, 18.6 \%, 17.9 \%, 6.5 \%, 1.6 \%, 2 \%, 1.6 \%$ respectively while agonistic response such as threat (14.6\%), attack 5.2\%, stare (3.1\%) and bite was $(1.1 \%)$ (i.e. agonistic responsive behaviour was 24\%.). Furthermore, look within the behaviour of monkey reaction showed that monkeys' response was high in only two type of human action i.e. taking photo and showing threat.

In Swayambhu, $78.1 \%$ of encounter was in presence of food and $21.9 \%$ in absence of food. When food was absent, threat was highest with $42.3 \%$, physical contact, $28.2 \%$, charge $14.1 \%$, passive $7 \%$, bite $5.6 \%$ and chase was lowest with $2.8 \%$ and When food was present, high occurring behaviour was passive behaviour with $65.6 \%$, physical contact $22.9 \%$, charge $5.1 \%$, chase $3.2 \%$, threat, $2.8 \%$ and bite was lowest with $0.4 \%$. 
Threat in absence of food was the most common and high form of aggression (42.3\%) than in presence of food (2.8\%) whereas in presence of food passive form of behaviour was high and common. Biting was high in absence of food $(5.6 \%)$ than in presence $(0.4 \%)$, chasing by monkey was high in food absence than presence but attacking (14.1\%) was more pronounced in absence of food than in presence with $5.1 \%$

\section{In Pashupati}

Monkey initiation of agonistic behaviour recorded to be $22.4 \%$ at Pashupati; $11.2 \%$ threat, $10.6 \%$ attack, $0.6 \%$ chasing. Passive behaviour accounted for $70.2 \%$ and physical contact (p.c.) $7.5 \%$.

In Pashupati, humans' threat behaviour was recorded to be about $37 \%$, feeding monkey $33 \%$, taking photo $11 \%$, chase $7 \%$, touching $7 \%$, moving close $3 \%$ and watch $2 \%$. Agonistic human behaviour was $44 \%$ (with threat and chase). In responsive monkey behaviour, agonistic response was $23.5 \%$ (attack $4 \%$ and threat 19.5\%) whereas non-agonistic behaviour such as eating, watching, leaving, fleeing resulted to be $75.1 \%$ while physical contact $1.9 \%$.

In Pashupati $72.7 \%$ of encounter was in presence of food and $27.3 \%$. In absence of food, threat had high share with $34.1 \%$. 29.5\% was accounted for passive behaviour, $20.5 \%$ physical contact and lowest was attack with $15.9 \%$ and within food presence, passive behaviour was dominant with $85.5 \%$, attack $8.5 \%$, threat and physical contact was $2.6 \%$ each and chase was least with $0.9 \%$.

Threat in absence of food was the most common and high form of aggression $(34.1 \%)$ than in presence of food $(2.6 \%)$ whereas biting, chasing by monkey was not observed in absence of food but attacking (15.9\%) was more pronounced in absence of food than in presence with $8.5 \%$.

\section{Association between variables in interactions}

There was significant association $(\mathrm{p}<0.05)$ between Type of initiator and Sex of individual of initiatior, Monkey behaviour and availability of food, Type of initiator and availability of food, Type of Encounter and Sex of monkey individual at both area. In addition, Food availability and Type of Encounter is significant at Pashupati but significant association does not exist ( $p>0.05)$ between Food availability and Sex of monkey individual in both area, Food availability and Type of Encounter at Swayambhu and Type of Encounter and Sex of monkey individual at Pashupati.

Agonistic behaviour shown by monkey in response to human behaviour was higher (24\% at Swayambhu and $23.5 \%$ at Pashupati) rather than the initiation of behaviour (23.1\% at Swayambhu and $22.4 \%$ at Pashupati).

In case of monkeys, female individual residing in Swayambhu were more interactive than male individual and in humans males were more interactive than female. Encounter at Swayambhu and Pashupati showed female monkey at Swayambhu is more interactive than female monkey at Pashupati and monkey from Swayambhu area (41.9\%) was more interactive than from Pashupati area (31.2\%) where as human from Pasupati area (68.8\%) shows high form of interaction than from Swayambhu $(58.1 \%)$.

At both study place, Swayambhu and Pashupati, interaction between Human and Monkey were mostly passive encounter and most encounter at both places were in absence of food.

\section{DISCUSSION}

Swayambhu and Pashupati area is religious and natural habitat for rhesus monkey but due to urbanization these area is now mixed with high human presence. Rhesus and Human interaction is 
common event in these locations. Humans have made this place a recreational spot for them. Rhesus monkey beside natural food source have adequate amount of food source these days as human are being major source for artificial food. Rhesus adapts to human population by increasing commensalism and thievery (Southwick and Siddqi 1994). Rhesus monkeys have well established its territory in the two studied area in association with urban elements that human has created. Once troop establishes its territory competition for food, space, and high density results in increase of aggressive behaviour (Ciani 1986).

In Pashupati interactions are high during morning and evening whereas in Swayambhu encounters occur during midday. There are more interactions in Swayambhu area than Pashupati area among monkey and human and adult monkey/humans are highly involved in the encounters. In both places monkey initiated interaction has been occurring in presence of food. But female monkey individual in absence and presence are likely to interact most frequently than male individual at Swayambhu whereas unlike Swayambhu male monkey individual at Pashupati are likely to interact most frequently than female. But male and female monkey individual are likely to interact with human in presence of food rather than in absence.

It is well observed now that from both study place agonistic behaviour between human and monkey occurs in absence of food rather than presence and human initiated aggression are likely to occur than monkey. At both places in absence of food human more frequently initiates aggressive encounter than monkey. But in presence of food monkey at Swayambhu are more prone to start aggression also at Pashupati human causes more aggression in presence of food as well.

\section{CONCLUSION}

Six type of behaviour is shown by monkey in form of passive and aggressive behaviour i.e. attack, bite, chase, physical contact, threat while humans showed seven types of behaviour; chase, feed, threat, watch, touch, take photo, move close. Monkeys were tolerant to everyday vendors and interacted less often with them. Interaction at Pashupati and Swayambhu follows different time pattern. Monkeys have developed a type of passive strategy around human whenever food is available. Field observations in natural setting provide the basic information needed on behavioural analysis for potential risk assessment from a particular species to humans. So, these kinds of behavioural study under naturalistic conditions helps in sound management and develop conservation strategies to resolve the human-wildlife conflict.

\section{ACKNOWLEDGEMENTS}

We would like to express our humble gratitude to Central Department of Zoology, T.U. for research acceptance and National Trust for Nature Conservation for partial support.

\section{REFERENCES}

Altmann, J. 1974. Observational study of behavior: sampling methods. Behaviour 49(3-4): 227-267.

Chalise, M.K. and Ghimire, M. 1998. Non-human Primate Census in Different Parts of Nepal. NAHSON 8: $1-4$.

Chalise, M.K. 2008. Primates Census in Kathmandu and West Parts of Nepal. Nepal. Journal of Natural History Museum 23: 60-64.

Nepalese Journal of Zoology | Online Volume 3 Issue 1 | November 2015 | Page 87 
Chalise, M. K. 2008a. Nepalka Samrakshit Banyajantu. Shajha Prakashan, Kathmandu Nepal, page $116+12$.

Chalise, M.K. 2013. Fragmented Primate Population of Nepal. In: L.K. Marsh and C.A. Chapman (eds.), Primates in Fragments: Complexity and Resilience, Developments in Primatology: Progress and Prospects, 329-356pp. DOI 10.1007/978-1-4614-8839-2_22, (C) Springer Science+Business Media New York 2013 Library of Congress C No: 2013945872.

Ciani, A.C. 1986. Intertroop agonistic behavior of a feral rhesus macaque troop ranging in town and forest areas in India. Aggressive Behavior 12(6): 433-439.

Ditchkoff, S., Saalfeld, S., and Gibson, C. 2006. Animal behavior in urban ecosystems: Modifications due to human-induced stress. Urban Ecosystems 9(1): 5-12.

Hinde, R.A. and Rowell, T.E. 1962. Communication by postures and facial expressions in the rhesus monkey (Macaca mulatta). In Proceedings of the Zoological Society of London, 138(1): 121.

McGlone, J.J. 1986. Agonistic behavior in food animals: review of research and techniques. Journal of Animal Science 62(4):1130-9.

Messmer, T. A. 2000. The emergence of human-wildlife conflict management: turning challenges into opportunities. International Biodeterioration and Biodegradation 45(3-4): 97-102.

Sade, D. S. 1973. An ethogram for rhesus monkeys I. Antithetical contrasts in posture and movement. American Journal of Physical Anthropology 38(2): 537-542.

Scott, J.P. and E. Fredericson. 1951. The causes of fighting in rats and mice. Physiological Zoology, 24: 273-309.

Southwick, C.H. and Siddiqi, M.F. (1994). Primate commensalism: the rhesus monkey in India. In Symposium "Les primates commensaux", tenu à Strasbourg, France, le 19 août 1994, à l'occasion du XIVe congrès de la Société internationale de Primatologie. Société nationale de protection de la nature et d'acclimatation de France, Paris (FRA).

Southwick, C.H., Siddiqi, M.F., Farooqui, M.Y. and Pal, B.C. 1976. Effects of artificial feeding on aggressive behaviour of rhesus monkeys in India. Animal Behaviour 24(1): 11-15.

Teas, J., Feldman, H. A., Richie, T. L., Taylor, H.G. and Southwick, C.H. 1982. Aggressive behavior in the free-ranging rhesus monkeys of Kathmandu, Nepal. Aggressive Behavior 8(1): 63-77.

Teas, J., Richie, T.L., Taylor, H.G., Siddiqi, M. F. and Southwick, C.H. 1981. Natural Regulation of Rhesus Monkey Populations in Kathmandu, Nepal. Folia Primatologica 35(2-3): 117-123. 